\title{
THE EFFECTS OF DIETARY ARTIFICIAL COLORS ON EXPERIMENTAL RATS
}

Hewahy, M. ${ }^{(1)}$; Lofty, Azza, O. ${ }^{(2)}$ and Elgohary, Fatma, K. 1) Department of Environmental Basic Sciences, Institute of Environmental Studies and Research 2) Laboratory of Outpatient Clinic, National Nutrition Institute (NNI).

\begin{abstract}
Recently the use of synthetic food coloring additives was increased and the levels of human exposure to such agents are very broad, thus feeding over long periods may continually possess potential hazards to the human health. Evaluation of the toxic effects of synthetic dyes Brilliant Blue, Tartrazine and Carmoisine were tested in rats by measuring their actions on renal, hepatic function, and body-weight gain. Rats were fed synthetic dyes supplemented diet, daily for 60 days orally in two doses, one low and the other high dose followed by serum sample collection for determination of urea, creatinine, uric acid, ALT, AST, ALP, glucose cholesterol, triglycerides and estimation of hemoglobin conc.

Our data showed a significant increase in cholesterol, triglycerides, ALT, AST, in addition to serum urea and creatinine levels in treated rats, while, they recorded a significant decrease in percentage of body weight change, and this significant change were more apparent in high doses than low doses.

Keywords: Food coloring additives, Brilliant Blue, Tartrazine, Carmoisine

\section{INTRODUCTION}

Food additives are used for various purposes, including preservation, coloring or sweetening. The wide range of food additives, running into more than 2500 items used to preserve, dye or enhance foods are a consequence of industrialization and the development of food processing technology. Most coloring agents are used to improve the overall attractiveness of food. A
\end{abstract}


number of natural and synthetic additives are used to color foods. Although synthetic coloring agents are continued to be used extensively, there has been a concomitant significant increasing interest concerning the using of natural colorants. Shadia,2010.

The Egyptian famous food additives which are used as coloring substances are Tartrazine and CarmoisineAmin, et al., 2010.

Many products contain Tartrazine like foods cotton candy, soft drinks, flavored chips, cereals, cake mixes, some of non-food products include Tartrazine such as soaps, cosmetics, shampoos and other hair products, also some medical preparations contain Tartrazine such as vitamins, antacids, medicinal capsules and certain prescription drugs. Walton et al., 1999.

Carmoisine present in food like jams, preserves, yoghurts, jellies, breadcrumbs, and cheesecake mixes. It is also present in oral Dene mouthwash. Amin et al., 2010.

Brilliant Blue, is a water-soluble coloring used in many baked goods, beverages, dessert powders, candies, cereals, drugs, and other products.Mahmood,2005.

Several studies have incriminated synthetic colorants to cause some adverse effects to human health.

\section{MATERIALS AND METHODS}

\section{Materials:}

A) Chemicals: Tartrazine a yellow color substance known as E102Walton, et al., 1999.Carmoisine a red color substance known as E122 or Food Red 
3Amin et al., 2010.

Brilliant blue FCF, color index no. 42090, E 133Neveen, 2006

Tartrazine, Carmoisine and Brilliant blue were in a solid state so we prepared two solutions of each substance (one low and the other high concentration) by dissolving the solid in distilled water, low doses of Tartrazine, Carmoisine and Brilliant blue were $0.5 \%, 0.25 \%$ and $0.75 \mathrm{gm} \%$ of diet respectively while high doses were $1 \%, 0.5 \%$ and $1.5 \mathrm{gm} \%$ of diet respectively according to Minister of Health and Population Decree No. 411 for the year 1997.

B-Animals: A total of 56 young malealbino rats (Sprague Dawley strain) weighting about 45-70 g were used in the present study. They were obtained from National nutrition institute, Cairo, Egypt. Animals were kept under observation for about 2 days before the onset of the experiment to exclude any intercurrent infection. They were maintained in stainless steel cages at normal atmospheric temperature of $27 \pm 5$ Cas well as under good ventilation. This study was approved by the Research Ethics Committee at National Nutrition Institute (NNI).

\section{C-Experimental design}

The rats were divided into 7 groups each of 8 ratsdivided as follows:

Group 1:Control group fed on standard diet was prepared according to Reeves et al., 1993.

Group 2:Fed on standard diet +Low dose of Tartrazine (E102) $0.5 \%$.

Group 3:Fed on standard diet + High dose of Tartrazine(E102) $1 \%$.

Group 4:Fed on standard diet + Low dose of Carmoisine (E122) $0.25 \%$.

Group 5:Fed on standard diet + High dose of Carmoisine (E122) $0.5 \%$. 
Group 6:Fed on standard diet + Low dose of brilliant blue (E133) $0.75 \%$.

Group 7:Fed on standard diet+ High dose of brilliant blue (E133) 1.5\%.

During the conditioning rats were weighted twice weekly and their food intake were calculated.The experimental lasted for 8 weeks, food intake and body weights (wt.) were recorded twice a week. Wastes collected after 8 weeks from beginning of experimental.

At the end of experimental period, blood samples were collected from the eye plexuses of animals by a fine capillary glass tubes and placed immediately on ice. Blood serum samples were collected into dry clean centrifuge tubes; the serum was separated after centrifugation for $10 \mathrm{~min}$ at $3000 \mathrm{rpm}$ and kept at $-20 \mathrm{CO}$ until biochemical analysis. The whole blood were collected on ethylene diamine tetra acetic acid (EDTA) tubes for immediate hemoglobin analysis.

D-Biological evaluation: The total food consumption of experimental period (8 weeks) was calculated, body weight gain (BWG) and feed efficiency ratio (FER) were determined according to Hsu et al., 1978.

\section{E-Biochemical analysis}

E.1. Liver functions: Alanine aminotransferase (ALT) and Aspartate aminotransferase (AST) activates were measured according to Reitman and frankel 1957. and Alkaline phosphatase (ALP) activates were measured according to Guder et al., 2001.

\section{E.2. Kidney functions:}

Serum creatinine was determined according to Bartles et al.,1972.

Serum Urea was determined according to Thomas et al., 2009. 
Serum uric acid was determined according to Young, 2000.

E.3. Hemoglobin (HB) was determined according to Drabkin, 1949.

E.4:. Glucose was determined according to Snacks et al., 2000.

E.5: Determination of cholesterol and triglycerides had been determined according to Guder et al., 2001.

F-Statistical Analysis: Results are expressed as Mean \pm SD the difference among groups where analyzed by analysis of variance (T.Test). The analyses were carried out using statistical package for the social science SPSS.Version (18) Computer Programs.

\section{RESULTS}

Table (1): Effect of food colorants concentration on body weight gain (BWG), food intake (FI) and feed efficiency ratio (FER) in rats.

\begin{tabular}{|c|c|c|c|c|c|c|c|}
\hline \multirow{2}{*}{ Groups } & \multirow[b]{2}{*}{$\begin{array}{l}\text { Control } \\
\text { Group } 1\end{array}$} & \multicolumn{3}{|c|}{ Lower dose } & \multicolumn{3}{|c|}{ Higher dose } \\
\hline & & $\begin{array}{c}\text { Tartrazine } \\
\text { Group? }\end{array}$ & $\begin{array}{l}\text { Carmoisine } \\
\text { Group } 4\end{array}$ & $\begin{array}{c}\text { Brilliant } \\
\text { blue } \\
\text { Group } 6\end{array}$ & $\begin{array}{c}\text { Tartrazine } \\
\text { Group } 3\end{array}$ & $\begin{array}{c}\text { Carmoisine } \\
\text { Group } 5\end{array}$ & $\begin{array}{c}\text { Brilliant bhue } \\
\text { Group } 7\end{array}$ \\
\hline BWG (gri) & $58.3 \pm 10.5$ & $62.8 \pm 53$ & $51.3 \pm 5.8$ & $48.0=7.0$ & $643 \pm 5.4$ & $43.3 \pm 11 j^{z}$ & $53.3=9.9$ \\
\hline $\mathrm{Fl}(\mathrm{gm})$ & $712.7=41.4$ & $794.3=45.20$ & $914.0=162.4$ & $819.5=3023$ & $749.2=92.1$ & $679.7=208.8$ & $6372=145.4$ \\
\hline $\operatorname{FER}(g n)$ & $0.08 \pm 0.01$ & $0.08=0.01$ & $0.05=0.01^{* 3}$ & $0.06 \pm 0.02$ & $0.09=0.01$ & $0.07=0.01^{4 *}$ & $0.08 \pm 0.01$ \\
\hline
\end{tabular}

All data presented as mean \pm standard deviation.

Significance p-value $<0.05$. $^{*}$

**highly significance $\mathrm{p}$-value $<0.01$.

Data in table (1) revealed that rats fed on low dose of Carmoisine and low dose of brilliant blue had decrease BWG compared to control group but the difference was not significant. It was also noticed that high dose of Carmoisine and high dose of brilliant blue had decrease BWG compared to 
control group but the difference was significant with high dose of Carmoisine and no significance with high dose of brilliant blue.

Concerning food intake, results showed that rats fed on low dose of Tartrazine, Carmoisine and Brilliant Blue had led to increased food intake compared to control group the differences were not significant. While food intake decrease in high doses of Carmoisine and brilliant blue groups compared to control group but the difference were not significant. As regards to feed efficiency ratio (FER), results showed that rats fed on low and high doses of Carmoisine highly significance $\mathrm{p} \leq 0.01$ compared to control group. But there were no any significance differences among other groups.

Table(2): Effect of food colorants concentration on liver function in male albino rats

\begin{tabular}{|c|c|c|c|c|c|c|c|}
\hline \multirow{2}{*}{ Groups } & \multirow[b]{2}{*}{$\begin{array}{l}\text { Control } \\
\text { Group } 1\end{array}$} & \multicolumn{3}{|c|}{ Lower dose } & \multicolumn{3}{|c|}{ Higher dose } \\
\hline & & $\begin{array}{c}\text { Tartraine } \\
\text { Group } 2\end{array}$ & $\begin{array}{c}\text { Carmoisine } \\
\text { Group } 4\end{array}$ & $\begin{array}{c}\text { Briliant blue } \\
\text { Group } 6\end{array}$ & $\begin{array}{c}\text { Tartrazine } \\
\text { Group } 3\end{array}$ & $\begin{array}{c}\text { Carmoisine } \\
\text { Group5 }\end{array}$ & $\begin{array}{c}\text { Brilliant blue } \\
\text { Group? }\end{array}$ \\
\hline $\begin{array}{l}\text { AST } \\
\text { (UL) }\end{array}$ & $141.2 \pm 14.7$ & $129.8=6.8$ & $175.3 \pm 13.5^{*}$ & $148.3 \pm 8.3^{k *}$ & $149.2 \pm 37$ & $153,7=30.8$ & $139.8 \pm 40.0$ \\
\hline $\begin{array}{l}\text { ALT } \\
\text { (UL) }\end{array}$ & $52.9 \pm 4.4$ & $62.4=11.7$ & $107.6=30.7 \times$ & $91.8=12.9^{* * 4}$ & $63.2=220$ & $95.9=25.2^{*}$ & $85.7=152^{k *}$ \\
\hline$A L P(n g d)$ & $189.0=28.2$ & $295.0 \pm 54.6^{24}$ & $242.5 \pm 50.4^{*}$ & $299=37.8^{* *}$ & $277.5=43.2^{4 *}$ & $256.7 \pm 55.7^{* 4}$ & $298=32.8^{k 4}$ \\
\hline
\end{tabular}

All data presented as mean \pm standard deviation.

*Significance p-value $<0.05$ $* *$ highly significance $\mathrm{p}$-value $<0.01$.

Data in table $(2)$ revealed a marked increase $(\mathrm{P}<0.05)$ in the serum AST level of treated group with low dose of group (4) compared to control group. Also resulted a highly significant $(\mathrm{P}<0.01)$ with low dose of group (6) compared to control group. And resulted no significance with other groups 
compared to control group. ALT conc. in serum showed a significant increase in group (5) while a highly significant increase in groups (4), (6), and (7)Compared to control group.

Regarding ALP, the results indicated a significant increase in group (4) while a highly significant increase in groups $(2,3,5,6 \& 7)$ compared to control group

Table(3): Effect of food colorants concentration on kidney function in male albino rats

\begin{tabular}{|c|c|c|c|c|c|c|c|}
\hline \multirow{2}{*}{ Groups } & \multirow{2}{*}{$\begin{array}{l}\text { Control } \\
\text { Group } 1\end{array}$} & \multicolumn{3}{|c|}{ Lower dose } & \multicolumn{3}{|c|}{ Higher dose } \\
\hline & & $\begin{array}{c}\text { Tartranine } \\
\text { Group } 2\end{array}$ & $\begin{array}{c}\text { Carmoisine } \\
\text { Group } 4\end{array}$ & $\begin{array}{c}\text { Brilliant } \\
\text { blue } \\
\text { Group } 6\end{array}$ & $\begin{array}{c}\text { Tartrazine } \\
\text { Group } 3\end{array}$ & $\begin{array}{c}\text { Carmoisine } \\
\text { Group } 5\end{array}$ & $\begin{array}{l}\text { Brilliant } \\
\text { blue } \\
\text { Group } 7\end{array}$ \\
\hline $\begin{array}{l}\text { Urea } \\
\text { (mg dil) }\end{array}$ & $23.5=1.2$ & $36.5 \pm 9.5^{* x}$ & $25.1=3.9$ & $220=5.8$ & $30.4=3.8^{* x}$ & $30.5=5.4^{* *}$ & $40.2=8.7^{* 0 *}$ \\
\hline $\begin{array}{l}\text { Creatinine } \\
\text { (mg dil) }\end{array}$ & $0.4=0.1$ & $0.8=0.1^{* *}$ & $0.8=0.2^{8 x}$ & $0.7 \pm 0.1 \mathrm{kx}$ & $0.6=0.1^{* x}$ & $0.7=0.1 \%$ & $1.0=0.1^{k x}$ \\
\hline $\begin{array}{l}\text { Uric Acid } \\
\text { (mg dil) }\end{array}$ & $15=02$ & $20=0.3^{* x}$ & $2.1=0.2^{* *}$ & $1.6=0.2$ & $20 \pm 0.3^{* x}$ & $1.5=0.5$ & $14=0.1$ \\
\hline
\end{tabular}

All data presented as mean \pm standard deviation.

*Significance $\mathrm{p}$-value $<0.05$. **highly significance $\mathrm{p}$-value $<0.01$.

Table (3), Showed a highly significant increase $(\mathrm{p}<0.01)$ in serum urea, in groups treated with synthetic color of low dose of Tartrazine, and high doses of Tartrazine, Carmoisine. And brilliant blue comparedto the control group. No significance was found among other groups.

Regarding creatinine conc. in serum showed a highly significant increase in all groups compared to control group.

The results of uric acid conc. in serum indicate a highly significant increase of groups $(2,3 \& 4)$ compared to control group. 
J. Environ. Sci.

Institute of Environmental Studies and Research - Ain Shams University

Table(4): Effect of food colorants concentration on hemoglobin and glucose in male albino rats

\begin{tabular}{|c|c|c|c|c|c|c|c||}
\hline Groups & & \multicolumn{3}{|c|}{ Lower dose } & \multicolumn{3}{c|}{ Higher dose } \\
\cline { 3 - 8 } Parameter & $\begin{array}{c}\text { Control } \\
\text { Group 2 }\end{array}$ & $\begin{array}{c}\text { Tartrazine } \\
\text { Group 2 }\end{array}$ & $\begin{array}{c}\text { Carmoisine } \\
\text { Group 4 }\end{array}$ & $\begin{array}{c}\text { Brilliant } \\
\text { blue } \\
\text { Group 6 }\end{array}$ & $\begin{array}{c}\text { Tartrazine } \\
\text { Group 3 }\end{array}$ & $\begin{array}{c}\text { Carmoisine } \\
\text { Group 5 }\end{array}$ & $\begin{array}{c}\text { Brilliant blue } \\
\text { Group 7 }\end{array}$ \\
\hline \hline HB & $12.8 \pm 1.3$ & $12.2 \pm 0.4$ & $12.0 \pm 0.7$ & $10.2 \pm 1.9$ & $10.8 \pm 1.1^{*}$ & $11.7 \pm 0.7$ & $11.4 \pm 1.5$ \\
\hline Glucose & $84.9 \pm 9.7$ & $89.5 \pm 24.4$ & $74.0 \pm 9.4$ & $81.4 \pm 19.0$ & $84.1 \pm 3.4$ & $77.4 \pm 12.3$ & $108.7 \pm 13.4^{* *}$ \\
\hline
\end{tabular}

All data presented as mean \pm standard deviation.

$*$ Significance p-value $<0.05 . \quad * *$ highly significance $\mathrm{p}$-value $<0.01$.

The data represented in table (4) revealed a significant decrease of $(\mathrm{p}<0.05)$ on HB in group (3) compared to control group while no significance in other groups. The results of Glucose conc. in serum indicate a highly significant increase $(\mathrm{p}<0.01)$ of glucose concentration was showed in group (7) compared to control group and no significant other groups.

Table(5): Effect of food colorants concentration on lipid profile in male albino rats:

\begin{tabular}{|r|c|c|c|c|c|c|c|}
\hline \multirow{2}{*}{ Groups } & & \multicolumn{3}{|c|}{ Lower dose } & \multicolumn{3}{c|}{ Higher dose } \\
\cline { 3 - 8 } & $\begin{array}{c}\text { Control } \\
\text { Group 1 }\end{array}$ & $\begin{array}{c}\text { Tartrazine } \\
\text { Group 2 }\end{array}$ & $\begin{array}{c}\text { Carmoisine } \\
\text { Group 4 }\end{array}$ & $\begin{array}{c}\text { Brilliant } \\
\text { blue } \\
\text { Group 6 }\end{array}$ & $\begin{array}{c}\text { Tartrazine } \\
\text { Group 3 }\end{array}$ & $\begin{array}{c}\text { Carmoisine } \\
\text { Group 5 }\end{array}$ & $\begin{array}{c}\text { Brilliant blue } \\
\text { Group 7 }\end{array}$ \\
\hline \hline Cholesterol & $56.4 \pm 7.0$ & $58.8 \pm 6.0$ & $76.3 \pm 19.6^{*}$ & $80.2 \pm 17.6^{*}$ & $69.7 \pm 17.9$ & $78.0 \pm 16.5^{* *}$ & $69.2 \pm 8.6^{* *}$ \\
\hline Triglyceride & $67.8 \pm 10.5$ & $73.3 \pm 11.1$ & $81.3 \pm 10.2 *$ & $87.3 \pm 17.2^{*}$ & $66.9 \pm 14.6$ & $91.9 \pm 15.2 * *$ & $85.1 \pm 9.5^{* *}$ \\
\hline
\end{tabular}

All data presented as mean \pm standard deviation.

$*$ Significance $\mathrm{p}$-value $<0.05 . \quad * *$ highly significance $\mathrm{p}$-value $<0.01$. 
The Table (5) indicates that a significant increase in cholesterol and triglycerides of Carmoisine and Brilliant Blue in both low and high doses when compared to control value. While no significant of Tartrazine in both doses (low and high) when compared to control group.

\section{DISCUSSION}

In this study some trials were adopted to throw a light on the side toxic effects and biochemical changes in some constituents in serum of experimental rats treated with 3 compounds (each of low and high doses) that are commonly used in Egyptian field of food additives. We considered low dose (double of ADI) because our young children in Egypt can consume a double of ADI (or more) daily in several products without control, in addition we used the high dose (a much higher than ADI) to evaluate the toxicity and health hazards of these additives on biochemical assay. High dose of Carmoisine showed a significant decrease in body-weight gain after 2 month while non significance in the percentage of body weight change of rats after treatment with $0.5 \%$ of diet \& $1 \%$ of diet tartrazine, $0.25 \%$ of Carmoisine, and $0.75 \%, 1.5 \%$ of diet brilliant blue for 8 weeks as compared with the control rats. These observations were in agreement with Shadia, 2010. This effect in growth is thought to be due to a reduced availability of nutrients caused by the rapid transit of food colorants through the upper segments of the gastrointestinal tract Aritsuka et al., 1989; and Takeda et al., 1992 and to colorant's inhibitory effects on the processes of digestion and absorption. 
However, there are many reports on weight loss in Carmoisine administered experimental animals Abu El- Zahab et al. 1997; El-Shamy et al., 1999; Marie et al., 1999; and Helal et al., 2000. Meanwhile, Osman et $a l ., 1995$ found that the synthetic food colorants caused a significant increase in the body weight gain of mice until the fourth month, followed by a significant decrease.

The present study revealed that a marked rats consuming low dose of Carmoisine and Brilliant blue exhibited a significant increase in serum AST and ALT compared to control group. On the other hand showed an insignificant change of AST activity of high dose of Carmoisine and Brilliant blue. These changes in liver function attributed to hepatocellular impairment which subsequently caused the release of greater than normal levels of intracellular enzymes into the blood. Elevated levels of the transaminases can signal hepatic disease, muscular dystrophy, and organ damage. Thus serum aminotransferases activities are known as toxicity markers in the study of hepatotoxicity caused by Chemicals Govindwar and Dalvi,1990.

Abdel-Rahim et al., 1989 found a significant increase in both serum AST and ALT of rats fed on chocolate brown HT for three months, and they attributed these changes in liver function to hepatocellular impairment which subsequently caused the release of greater than normal levels of intracellular enzymes into the blood.

Furthermore, Abu El-Zahab et al., 1997 investigated the effect of three different synthetic chocolate colorant agents in rats whose diets were supplemented with chocolate colors A and B (Sunset yellow, Tartrazine, 
Carmoisine and brilliant blue in varying concentration, which revealed a significant increase in serum aspartate and alanine transaminases (AST and ALT respectively). Attia et al., 2005 showed significant increase in the activity of the serum enzymes ALT and AST of benzene sulfonic acid sodium treated rats, it may be taken as a good index for disturbance in the liver function.

On the other hand Borzelleca and Hallagan, 1988 and Ford et al., 1987 stated that Tartrazine and Carmoisine caused insignificant changes in rat serum AST and ALT. Yet these contradictory results were recorded after long-term (1-2years) toxicity studies which may indicate an adaptation mechanism on the part of the liver. While, Salah, 1994 found that the synthetic food colorants inhibited the activity of AST.

Regarding ALP, the results indicated a significant increase in low dose of Carmoisine and a highly significant increase in all groups compared to control group.

A rise in the alkaline phosphatase (ALP) occurs with all forms of cholestasis, particularly with obstructive jaundice. It is also elevated in diseases of the skeletal system such as hyperparathyroidism, rickets and osteomalacia, as well as fractures and malignant tumors.

In the same aspect, Attia et al., 2005 recorded a significant increase in the activity of the serum alkaline phosphatase (ALP). The increase in ALP activity is attributed to early cholestasis liver damage which primary effects the liver parenchyma and is a key for an early diagnosis of infiltrative diseases El-Elaimy and El-Nabi, 1990. However, the increased serum activity of ALP is not specific only for liver tissues but also many other tissues may 
be affected especially the gastrointestinal tract, the intestinal microvilli membrane is rich in ALP Young et al., 1981, Mahmood et al., 2005,ElShamy et al.,1999observed a significant increase in serum ALP in rats treated with a green-coloring dye.

Also, Abu El-Zahab et al., 1997 investigated the effect of chocolate colors (sunset yellow, Tartrazine, Carmoisine and brilliant blue in varying concentrations), which revealed a significant increase in serum alkaline phosphatase (ALP). On the other hand Borzelleca and Hallagan 1988 and Ford et al., 1987stated that Tartrazine and Carmoisine caused insignificant changes in rat serum ALP.

These results are in accordance with Sharma et al., 2006 who found that the two doses of Tomato Red (blend of Carmoisine and Ponceau 4R) showed a significant increase in alkaline phosphatase activity when Swiss albino mice consumed these colorants for 21 days as short term or 42 days as long term. The present findings are in agreement with Helal et al., 2000 who found that oral administration of synthetic or natural colorants induced a marked increase in the serum AST and ALT level of all treated groups after 30 days of treatment.

Our study demonstrated that the daily intake for 60 days of Tartrazine, Carmoisine and Brilliant blue either low or high doses exhibited a significant increase in serum creatinine, urea and uric acid concentration when compared with control rats, while high dose of Tartrazine, Carmoisine and Brilliant blue exhibited a significant increase more than low dose in serum creatinine level (Table 3). Our results are in agreement with Helal et al., 2000 who found that 
a significant elevation in serum creatinine and urea in rats consumed a synthetic or natural food colorants after 30 days of treatment Furthermore, the present findings are in accordance with data reported by Ashour and Abdel Aziz, 2009 who observed a significant elevation in serum creatinine and urea level of rats dosed with organic azo dye (fast green) orally for 35 days. We believe that the significant elevation in urea and creatinine levels is closely related to the impairment of renal function. These results are in agreement with Varely, 1987 who determined that the blood urea can be increased in all forms of kidney diseases such as hydro nephrosis congenital cystic, kidney renal tuberculosis, condition in which deposition of calcium occurs as hypervitaminosis D.

Further, Attia et al., 2005reported a significant increase in the concentrations of serum creatinine and uric acid after seven weeks administration of BSAto rats was observed.

While, Chambers et al., 1966 and Carpanini et al., 1978 found that chocolate brown HT had no effect on renal function after both short-term and long - term toxicity studies in rats. Also, Ford et al, 1987 found insignificant changes in blood urea in rats fed on Carmoisine. Besides, Abu El-Zahab et $a l ., 1997$ found that blood urea and serum creatinine in rats supplemented with synthetic food colors remained unchanged throughout the experiment.

The increase in serum cholesterol, and triglyceride levels obtained in this study are in accordance with results reported by previous studies Abou ElZahab et al., 199); Himri et al., 2011who observed significant increases in serum total lipids, cholesterol and triglycerides in rats whose diets were supplemented with some food colorants in varying concentrations. 
The current results of this study are in a contrary with Sharma et al., 2006 who reported that two doses of tomato red (blend of Carmoisine and ponceau 4R) showed a significant decrease in serum total cholesterol and triglycerides when Swiss albino mice consumed these colorants for 21 days as short term or 42 days as long term. Also, these results are in opposite with those reported by Ashour and Abdel Aziz, 2009 who noticed a significant reduction in serum total cholesterol and triglycerides level when food color azo dye (fast green) was consumed orally to male albino rats for 35 days.

Results of the present investigation revealed that food colorants caused a high significant decline in hemoglobin content agreement with the present work, Shadia et al.,2010 demonstrated a reduction of hemoglobin when Tartrazine was administered to the diet of mice. Furthermore, by long-term feeding study on Red $2 \mathrm{G}$ dye at the dose of $130 \mathrm{mg} / \mathrm{kg}$ b.wt. /day in the mouse and $32 \mathrm{mg} / \mathrm{kg}$ b.wt. /day in the rat, the spleen showed enlargement with an increased deposition of iron. In the mouse, accelerated erythropoiesis was observed and the rats showed necrosis of elastic. Above $0.5 \%$ of dye in the diet, adverse effects were observed in the spleen, liver and bone marrow. Heinz body formation in the erythrocytes was also observed in both species of rodents (rats\& mice) WHO,1981. In The same aspect, Abu El-Zahab et al., 1997 mentioned that rats supplemented with sunset yellow, Carmoisine and brilliant blue for 60 days exhibited a significant decrease in hemoglobin content as well as red cell count. These changes induced by food colorants may be due to the prevention of red blood cell synthesis via inhibition of erythropoiesis in the bone marrow. 
On the other hand, Shaker et al., 1989 noted an increase in hematological content of rats received $0.1 \%$ chocolate brown color $(0.1 \% \mathrm{w} / \mathrm{w})$ consisting of Tartrazine, NovalCoccine, Carmoisine and Indigocarcarmine.

While, Hooson et al., 1975 found that indigo carmine had no effect on the total erythrocytes count. Moreover, Ford et al., 1987 stated that Carmoisine (given in high doses for 6 months) did not cause any changes in the hematological investigations of rats.

Also, Borzelleca \&Hallagan 1988 using Tartrazine in high doses and long terms on rats revealed insignificant effects on the hematological parameters of these animals.

The present study, exhibited no significant change in serum glucose of color foods compared to control group Table (4) with short term 2 months show a highly significance in fasting serum glucose fed on low or high doses from Tartrazine ,Carmoisine and brilliant blue. The present study are in a contrary with Amin et al.,2010 who demonstrated that high dose of synthetic color (Tartrazine at $500 \mathrm{mg} / \mathrm{kg} \mathrm{b.wt)}$ or low dose of Tartrazine $(15 \mathrm{mg} / \mathrm{kg}$ b.wt) caused no significant increase in serum glucose concentration. The present study are in agreement with Himri et al., 2011 who found that a significant increase in serum glucose concentration when administration synthetic color (Tartrazine and sulfonic acid) at low and high dose compared to control group.

The elevation of glucose level can be explained by stimulation of glycogenolysis and gluconeogenesis by the liver with a temporarily loss of endocrine functions of pancreas leading to hyperglycemia Al-Shinnawy, 20009. 
J. Environ. Sci.

Institute of Environmental Studies and Research - Ain Shams University

\section{CONCLUSION}

Food azo dyes like Tartrazine, Carmoisine and brilliant blue can affect adversely and alter biochemical markers in vital organs e.g. liver and kidney not only at higher doses but also at low doses. Tartrazine and Carmoisine not only cause changes in hepatic and renal parameters but also their effect become more risky at higher doses because they can induce oxidative stress by formation of free radicals. Therefore, it is necessary to create consumer awareness regarding the ill effects of these food azo dyes and mention the type and concentration of each material added to food.

Based on our results, we believe that more extensive assessment of food additives in current use is warranted

\section{REFERENCES}

Abdellah A. Dafallah ,Abdelmonem M. Abdellah, Emam A. Abdel.Rahim,Sherif H. Ahmed,(2015). Physiological effects of some artificial and natural food coloring on young male albino rats. J, Journal of Food Technology Research, 2(2): 21-32.

Abdel-Rahim EA, Ashoush YA, Afify AS and Hewedi F (1989): "Effects of some synthetic food additives on blood hemoglobin and liver function of rats." Minufiya J. Agric. Res., 14 (1), 557.

Abu El-Zahab HSH, El-Khyat Z, Sidhom G, Awadallah R, Abdel-al W and Mahdy K (1997): Physiological effects of some synthetic food coloring additives on rats. Boll.Chim.Farm., 136(10): 615-627.

Al-Shinnawy, M.S., (2009).Physiological effect of a food additive on some hematological and biochemical parameters of male albino rats.Egypt. Acad. J. Biolog. Sci, 2(1): 143-151 
Amin, K., I.H. Hamid and A. AbdElsttar, (2010). Effect of food azo dyes Tartrazine and Carmoisine on biochemical parameters related to renal, hepatic function and oxidative stress biomarkers in young male rats. Food and Chemical Toxicology, 48(6): 2994-2999.

Aritsuka T, Tanaka K and Kiriyama S (1989): Protection of amaranth FD and C Red No. 2 toxicity by beet dietary fiber and its ability to slow down small intestinal transit speed in rats. Nippon NogeikagaruKaishi., 63: 1213-1219.

Ashour, A.A., Abdel Aziz, I., (2009): Role of fast green on the blood of rats and thetherapeutic action of vitamins $\mathrm{C}$ or E. Int. J. Integr. Biol. 6 (1), 6-11.

Attia ZI, Basyuni MA, Hegazi MA and Okba SG (2005): Effect of benzene sulfonic acid, the degraded derivative of the sunset-yellow beverages, coloring dyes on the physiology and growth rate of young rats. Egypt. J. Zool., 45: 373-387.

Bartles,H.;BohmermM. And Heirli,C. (1972): Colorimetric kinetic method of determination of creatinine.Clin.Chem.;37,193.

Borzelleca, J.F. and Halogens, J.B. (1987): Life time toxicity/Carcinogenicity Study of FD \& C Red No. 3 in mice. J. FD. Chem. Toxicol, 25: 73.

Carpanini FMB, Butler worth KR, Gaunt IF, Kiss IS, Grasso P and GanqolliSD (1978):long-term toxicity, $\mathrm{v}$ studies on chocolate brown Ht in rats. Toxicology 11 (3), 303.

Chambers PL, Hunter CG and Stevenson DE (1966):Short-term study of chocolate brown HT in rats. Fd comet. Toxicol., 4: 155..

El-Elaimy A and El-Nabi SEH (1990):Influence of thiola on pesticide induced intoxication. II. Preventive effect of liver damage. J. Environ. Sci., 1: 67-82.

El-Shamy KAI, Khadr ME, Morsy FA and Hassanin MM (1999):Toxic effect of some food additives on vital activities of albino rat,

Greencolor (tartrazine and brilliant blue). Egypt. J. Zool., 32: 417-440 
Ford GP, Stevenson BI and Evans JG (1987):long-term toxicity study of carmoisine in rats using animals e ; Posed in utero. Food. Chem. Toxic., 25 (12), 919.

Govindwar SP and Dalvi RR (1990):Age dependent toxicity of acorn extract in young and old male rats. Vet. Hum. Toxicol., 32:23-6.

GuderWG,Zawta B et al ., (2001): The quality of Diagnostic Samples 1st ed. DarmstadtGITVerlag,p.22-3.

Helal EGE, Zaahkouk SAM and Mekkawy HA (2000): Effect of some food colorants (synthetic and natural products) of young albino rats ILiver and kidney functions. The Egypt. J. Hosp. Med., 1: 103 113.

Himri, I., H. Bellahcen, F. Souna and F. Belmakki, (2011) .A 90-day oral toxicity study of Tartazine, a synthetic food dye, in westsr rats.International Journal of Pharmacy and Pharmaceutical Sciences, 13(3): 159-169.

Hooson, J.; Gaunt, I.F.; Kiss, I.S.; Grasso, P. and Butterworth, K.R. (1975): Long-term Toxicity of Indigo carmine in mice. Food. Cosmetic. Toxicol., 13: 167.

Hsu, H. W., Sutton, N. E., Banjo,M. O., Satterlee, L.D. and Kendriek, J.G.(1978): The CRER and assays for protein quality . J. FD. Technol., 12: 69-74.

Mahmood S, Kaur K, Mittal N and Mahmood A (2005). Giaraialamblla: expression of alkaline phosphatase activity in infected rat intestine ExpParasitol., 110(2): 91-95.

Marie MS, Agag BI, El-Kholi MMA (1999): Physiological and biochemical responses induced by the synthetic food coloring additives Tartrazine and ponceau 4R (new coccine) in rats. Egypt- J. Zool., 32: 183-201.

Minister of Health and Population Decree No. 411 for the year (1997).

Neveen,H.mahmoud J. (2006): Toxic effects of the synthetic food dye brilliant blue on liver, kidney and tests functions in rats. Egypt. Soc. Toxicol. 34: 77-84. 
Osman MA, Afifi A, Hussein RM, Kamilia B, Abdel Aziz and Salah SH (1995): Long-term biochemical and genotoxicity studies of four synthetic food and drug colorants in mice- Bull. Fac. Pharm. Cairo Univ., 33(1): 13-21.

Reeves PG, Nielsen FH and Fahey GC (1993) AIN-93Purified diets for laboratory rodents: Final report of the American Institute of Nutrition ad hoc writing committee

on the reformulation of the AIN-76A rodent diet. Journal of Nutrition 123(11): 1939-1951.

Reitman ,A.andFrankel,S. (1957): Colorimetric method for the determination of serum glutamic oxaloacetic and glutamic pyruvic transaminases,Am.j.Clin.path,; 28-56.

Shadia Ali Radwan; Ahmed Riad El-Sayed; Mohammed Salah Al-Shinnawy and Omnia Nasr Abdel-Rahman Mohamed,(2010):

Hematological And Biochemical Changes Induced By Amaranth Impact On Male Albino Rats,40: 335-349

Shaker AMH, Ismail IA and El-Nemr SE (1989): Effect of different food stuff colorants added to casein diet for biological evaluation. Bull. Nutr, Isnt. Cairo, Egypt. 9(1): 77-86.

Sharma, S., Goyal, R.P., Chakravarty, G., Sharma, A, (2006): Tomato red toxicity: hematological and serological changes in the blood of Swiss albino mice, Musmusculus. Ind. J. Environ. Sci. 10 (2): 145-148.

Snacks DB, Bruns DE, Goldstein DE.MacLaren NK, Mc Donald JM,Parrott M.(2002): Guidelines and recommendations for laboratory analysis in the diagnosis and management of diabetes mellitus. ClinChemi, 48:436-

Takeda H, Nakajima A and Kiriyama S (1992): Beneficial effects of dietary fiber on the upper gastrointestinal transit time in rats suuferingfrom a toxic dose of amaranth. Biosci. Biotech. Biochem., 56: 551-555.

Thomas (1998).ClinicallaboratoryDiagnostics.1sted.FrankfurtTH-Books veragsgesellschaft; $p .374-7$. 
Varely, H., (1987).Practical Clinical Biochemistry, sixth ed. London Heinemann Medical Books. pp. 477-549.

Walton, K., Walker, R., Sandt, J.J.M., Castell, J.V., (1999): The application of in vitro data in the derivation of the acceptable daily intake of food additives. Food Chem. Toxicol. 37 (12), 1175-1197.

WHO (1981): Toxicological evaluation of certain food additives and contaminants. Food Additive Series No. 16, World Health Organization, Geneva.

Young GP, Yeldin ST and Alpers DH (1981): Distribution of soluble and membranous forms of alkaline phosphatase in the small intestine of the rat. Biochemica Biophysica Acta., 676: 257-265.

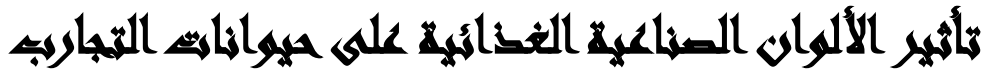

\section{$[r]$}

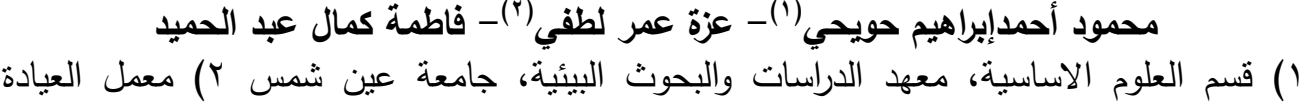
الخارجية، المعهد القومي للتغذية الاسنة

\section{المستخطي}

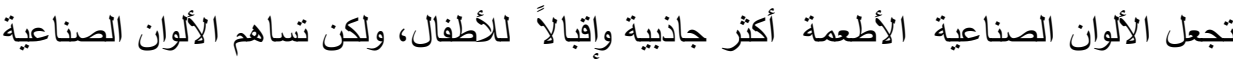

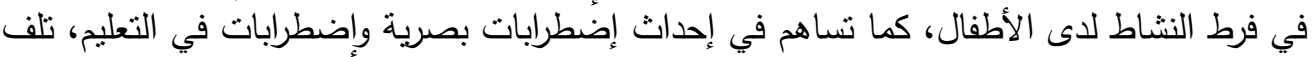
الأعصاب وقد تكون مسببة للسرطان.

تم تقييم التأثيرات السامة للأصباغ الإنية الصطناعية (بريلانت بلو وتارترازين وكارمويزين) علي

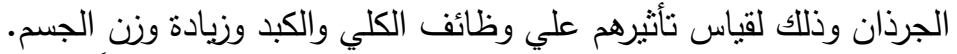

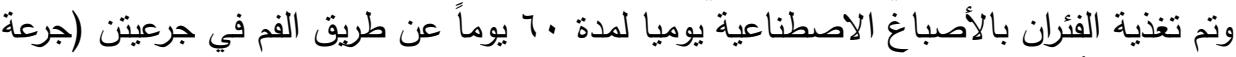

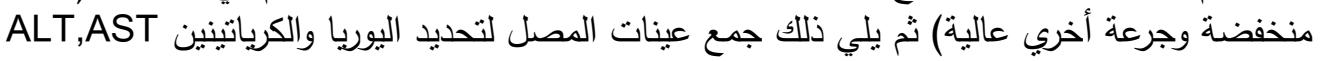
فوسفاتيز قلوي، الكوليسترول في الدم، الدهون الثناثية وتقدير الهيموجلوبين والجلوكوز .

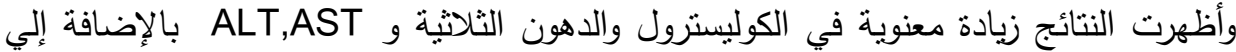

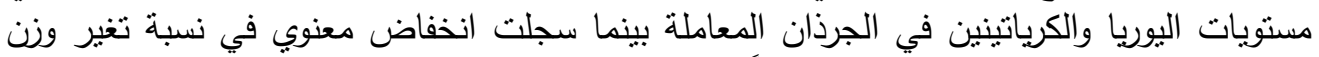
الجسم وكان هذا التغير الكبير أكثر وضوحاً في الجرعات التينات العالية عن الجرعات المنخفضة. 